Arboriculture \& Urban Forestry 2016. 42(1): 46-57

ISA

\title{
Determining Public Values of Urban Forests Using a Sidewalk Interception Survey in Fredericton, Halifax, and Winnipeg, Canada
}

\author{
Camilo Ordóñez, Peter N. Duinker, A. John Sinclair, Tom Beckley, \\ and Jaclyn Diduck
}

\begin{abstract}
With the majority of Canada's population concentrated in cities, it is important to determine what people consider important in urban nature. The concept of values can help illustrate what people consider important in urban nature beyond utilitarian considerations. This is the case for urban forests. However, many studies about public opinion on urban forests do not capture expressions of importance, focus on all the trees of the city, or provide respondents with a direct experience of urban forests. In Canada, most assumptions about Canadian urban forest values are based on results from the United States.

In this study researchers present and analyze urban forest values data gathered with a sidewalk interception survey in the cities of Fredericton, New Brunswick; Halifax, Nova Scotia; and Winnipeg, Manitoba, Canada, to address some of these limitations. Respondents were asked to rate the level of importance of urban forests and mention the reasons. Results show that respondents rate the urban forest at a high level of importance and the reasons for this are aesthetics, air quality, shade, and naturalness, among other themes. There was a tendency for older people, women, and non-students to rate urban forests at a higher level of importance. Weather, related to time of year of survey delivery, has a discernible influence on the way value themes are distributed in the data. The study authors infer that this method helps capture data on respondents' psychological states instead of their intellectual awareness as to what they consider important about urban forests.

Key Words. Canada; Fredericton; Halifax; Public Perception; Street Intercept Surveys; Survey; Urban Forest Attitudes; Urban Forest Values; Winnipeg.
\end{abstract}

Trees are the dominant vegetation of many cities and provide many services to people (Nowak et al. 2001). Understanding what people consider important in urban forests, defined here as all the trees in a city, is vital for their management (Dwyer et al. 1991). Considering urban citizens, or the public, in urban forest management goes beyond informing them about trees and taxing them for tree care (Clark et al. 1997). Assessing what the public considers important in urban forests is crucial for complementing, enhancing, or broadening what guides their management.

In determining what the public considers important about urban forests, a diverse array of psychosocial terms have been used, including attitudes, preferences, concerns, values, benefits, and services. This terminological diversity creates challenges for integrating findings on how people assign importance to urban forests. The study authors discuss these terms and their associated research here. It is not the researchers' intention to provide an exhaustive review of the literature, but rather to focus on the basic interpretations of these concepts, and discuss their advantages and disadvantages in capturing what the public considers important about urban forests.

The literature on environmental attitudes, preferences, and concerns focuses on monitoring the environmental orientation of demographic constituencies (Liere and Dunlap 1980; Heberlein 2012). It is interested in correlating people's care for the environment with age, education, income, urban and rural lifestyles, and sex, among other demographic characteristics (Dietz et al. 1998). Under this umbrella, some urban forest studies have demonstrated that most people have a positive attitude towards urban trees (e.g., Kalmbach and Kielbaso 1979; Getz et al. 1982; Sommer et al. 1989; Zhang 
et al. 2011). Women, high-income residents, those affiliated with environmental organizations, and those who have a tree in front of their home, may have a more positive attitude towards urban trees (Gorman 2004; Jones et al. 2013). Studies focusing on the reasons why people have a positive attitude towards urban trees state that the most common reasons are aesthetics, shade, and property values (e.g. Sommer et al. 1990; Schroeder and Ruffolo 1996). However, many of these studies provide few insights about how people assign environmental, ecological, psychological, or sociocultural importance to urban forests. Moreover, many of these studies result in a list of reasons of why people do not like urban trees, making it difficult to understand people's priorities.

A notable contribution to understanding how people assign importance to the urban forest is by studies of urban forest services, benefits, and values. In its widest definitions, an ecosystem service refers to natural processes that satisfy human and non-human needs (Fisher et al. 2009). The literature on urban forest services has contributed immensely to researchers' understanding of what urban trees do to influence the quality of life of urban citizens and the economic aspects of urban forests (Roy et al. 2012). However, this research is usually not based in public opinion. Moreover, by striving to quantify services through monetary valuation methods, most of this research does not capture unquantifiable psychosocial themes (see Ruckelshaus et al. 2013).

An ecosystem benefit generally refers to what people receive from an ecosystem, not just in terms of life-supporting functions, but also in psychosocial and economic terms (Dwyer et al. 1992; McPherson 2003). In one important study, respondents identified shade and calming effects as the most important benefits of urban forests, with female and older respondents, and those with a higher income, more likely to agree that urban trees were important to life quality (Lohr et al. 2004). However, many such benefit explorations also end up in a list of negative concerns, such as allergies or leaf collection (e.g., McPherson and Simpson 2002; Lohr et al. 2004). Furthermore, some benefit studies have attempted to quantify them monetarily (e.g., McPherson 2003; Payton et al. 2008), thus missing many psycho-social themes.

Values are broadly conceived as the fundamental belief system informing a person's opinions and conduct (Rokeach 1973) and are inherently positive constructs (Schwartz and Bilsky 1990). Despite the fact that a value is not a quality of an object itself (Schultz 2002), people can express a rich emotional and cognitive association with a natural element or an ecosystem (Dutcher et al. 2007). Some researchers argue that values are deeply considered, stable constructs, and cannot be explored through objects because this risks them being confused with attitudes or preferences, which are variable (Schwartz 1992; Rohan 2000). A criticism of the literature based on this notion of values is that most of it does not effectively capture the values people hold in relation to nature and the environment (Dietz et al. 2005). Most researchers interested in understanding ecosystem values are not concerned with whether people have a positive attitude towards nature or not, but rather how they assign importance to nature (Dietz et al. 2005; Reser and Bentrupperbäumer 2005). Based on this interpretation, people's values have been explored in specific natural contexts, such as forests. Research shows that people value forests due to their contributions to human health and well-being, and their intrinsic ecological importance (Bengston 1994; Treiman and Gartner 2005; Owen et al. 2009).

Based on this discussion, the research based on the concepts of preference, concern, attitude, service, and benefit provides very useful insight on how people perceive urban forests, but it is limited in capturing expressions of importance related to them. Many see values as a better concept for expressing how people assign importance to nature (Dietz et al. 2005) and defining what is important to sustain about an ecosystem (Lockwood 1999). Although there are clearly other constraints to urban forest management, including landform and other geographical considerations (Conway and Hackworth 2007), public values in relation to urban forests are vital determinants of the direction of urban forest management.

Taking this into consideration, one can identify some gaps in the urban forest values literature. First, urban forest values are frequently explored in spaces, conceptually or physically, that do not represent the ecosystem as a whole or that encompass other natural elements besides trees. Some relevant studies have focused on street trees (Flannigan 2005; Schroeder et al. 2006), urban woodlands (Tyrväinen et al. 2007; Hunter 2001), or generic spaces, such as greenspaces (Balram and Dragievi 
2005; Budruk et al. 2009), open spaces (Chiesura 2004), and greenways (Gobster and Westphal 2004) that do not necessarily contain trees. In some studies, values are explored in the context of damage events (e.g., hurricanes, Hull 1992), which generate interesting results but are difficult to replicate. Most attitude and benefits studies have relied on phone and postal surveys with only a few prompted categories (e.g., Kalmbach and Kielbaso 1979; Schroeder and Ruffolo 1996; Johnston and Shimada 2004; Lohr et al. 2004; Schroeder et al. 2006; Zhang and Zheng 2011). These methods limit respondents' expressions and direct experiences of the urban forest, a crucial aspect in capturing people's values (Satterfield 2001; Owen et al. 2009). Although visual-elicitation (e.g., Tyrväinen et al. 2007) and qualitative (e.g., Chiesura 2004; Jay and Schraml 2009) studies address some of these limitations, they found it difficult to avoid small sample size and participant self-selection. Finally, most studies on public opinion about urban forests are from the U.S. and Europe. Studies in other countries and continents are rare, and assuming similar urban forest values between countries may be inadequate.

To address these gaps, this paper reports the results from a study that elicited information on how the public assigns importance to urban forests in three Canadian cities using a sidewalk interception survey method. This study was different in four important ways: 1) it captures expressions of importance from respondents, instead of expressions of preference or attitudes towards urban forests; 2) it focuses on all the trees of the city, or urban forests, instead of other elements of urban nature, such as open greenspaces (with no trees); 3 ) it focuses on ideas that emerge from interpreting verbatim responses instead of using prompted categories; and 4) it provides respondents with a direct experience of urban forests by non-selectively recruiting them from urban treed spaces, an important aspect of some qualitative studies where respondents express themselves in more intimate ways, in contrast of reacting to a question out of context (see Jay and Schraml 2009). Canadian urban forests are ideal to explore urban forest values, as around $80 \%$ of Canada's population is concentrated in urban areas (Statistics Canada 2006), and urban forests are deemed an important element of Canadian urban sustainability (van
Wassenaer et al. 2000). Although there are some local efforts to capture public urban forest values, some of these do not provide an understanding of people's priorities (e.g., Fraser and Kenney 2000). Other studies, in some ways, are complementary qualitative explorations to this study (e.g., Peckham et al. 2013; Sinclair et al. 2014), but suffer of a small sample size. The current study addresses these limitations and complements these efforts.

\section{METHODS}

A sidewalk interception, or street-intercept, survey method is based on a non-selective recruitment of respondents from the streets in direct contact with their surroundings to gain quick access to their information (Lewis-Beck et al. 2003). This method can potentially provide high-quality data with reliable demographic profiles (Mulhall et al. 2008). Researchers applied this method to capture data on how people assign importance to the urban forest in three Canadian cities were chosen because they were home to the collaborating universities. A one-page questionnaire was designed and delivered orally to non-selectively recruited pedestrians from the street. The survey took three to five minutes to complete. It was carried out in local streets of Fredericton, New Brunswick; Halifax, Nova Scotia; and Winnipeg, Manitoba, between 2010 and 2012 in the summer or autumn months (before leaf fall). The surveys were done from late August to early November in Fredericton and Halifax and from mid-July to late September in Winnipeg.

Four survey delivery sites were chosen in each city based on a combination of high pedestrian traffic and onsite treed spaces, including sites close to forested urban parks, commercial streets with a few trees, and mixed sites with mature trees (e.g., Odell Park, in Fredericton; corner of Spring Garden and South Park, in Halifax; Assiniboine Park entrance, in Winnipeg). Researchers delivering the survey, termed here interviewers, had the instruction of achieving at least 100 responses at each location. To avoid confusion, the survey used lay terms to refer to urban forests. Urban forests were referred to as "all the trees in the city," and urban-forest values were captured as answers to the question, "What do you consider important about the trees in the city?" 
Data recorded included the following: 1) sampling characteristics, including interviewer, location, date, and weather (based on two temperature descriptions, "cold" or "hot"; these helped distinguish between a hot day in the summer and a cold day in autumn, thus reducing subjective impressions); 2) answers to the question on what degree of importance does the respondent place the trees in the city, on a 1-5 scale, with 5 being highest [a similar ordinal rating scale to that of Schroeder et al. (2006), but focused on all the trees in the city and not just on the tree in front of a respondent's home]; 3) answers to the question on what makes the trees in the city important, with up to two verbatim responses; and 4) demographic characteristics. For demographic characteristics, and based on the literature review, the study authors recorded the following: decade in which respondents were born (from 1920s to 1990s); sex (female/male); occupation (in their own words); and whether they were members of any environmental group (yes/no). Based on pilot surveys, the authors recognized that many people do not have any recollection of or desire to disclose personal information related to their place of residence or economic situation, even if these are factors influencing people's perception of the urban forest, as suggested by the literature review.

Verbatim nominal data were processed further to facilitate analysis. Codes for occupation and value responses were assigned using interpretative analysis techniques focused on condensing textual information into themes (Strauss and Corbin 2008). Since there were almost 25 occupation codes, termed here original occupation codes, and given the high number of student respondents, occupation data were also re-coded as student/ non-student (Table 1). Moreover, the two verbatim responses to the question, "What makes the trees in the city important?" (termed first and second mentions) were converted into codes of value themes. Although the codes were grounded in the data, the final terms reflect terminology used in the literature (see Peckham et al. 2013). Some value codes were combined when the same idea was conveyed (e.g., oxygen became air quality; see RESULTS and DISCUSSION). The code of environmental quality referred to ideas implying improvement or cleaning of the environment,
Table 1. Coding examples for the verbatim responses related to occupation and what respondents considered important about the urban forest, based on the survey results from Fredericton, Halifax, and Winnipeg.

\begin{tabular}{lll}
\hline Item & Verbatim response & Code \\
\hline Occupation & "Administrative assistant" & Management \\
& "Full-time mom" & Home parent \\
& "Dlerk at local store" & Customer service \\
& "Pensioner" & Artist \\
& "Priest" & Retired \\
& Faith professional \\
"Gives a better look to the city" & Aesthetics \\
& "Improves the environment" & Environmental \\
& "Filters the air" & quality \\
& "Creates a buffer zone for & Air quality \\
animals" & Biodiversity \\
"Create oxygen" & Oxygen ${ }^{z}$ \\
"Takes away from the concrete & Naturalness \\
feeling" & \\
"Makes me feel good to see & Personal well-being \\
greenspace" & \\
"Makes me feel at home" & Sense of place \\
"Because of David Suzuki" & Other \\
\hline
\end{tabular}

${ }^{z}$ Oxygen code becomes air quality (see DISCUSSION).

whereas more specific ideas also related to environmental quality, such as regulation of air pollutants, soil quality, water quality, and noise, were coded separately (Table 1). No responses were coded as "no response." Themes that were mentioned fewer than ten times and themes that were difficult to categorize were coded as "other" (Table 1).

Data were imported into statistical software (SPSS) and analyzed. Since it is mostly unnecessary to use complex analysis for simple numerical ratings given that simple procedures can yield reliable results (Schroeder 1984), researchers analyzed the data on ratings of importance for variance (one-way ANOVA), using the calculated mean (the median was not used given that it was always the same $=5$ ) according to all independent variables including city, weather (hot/cold), date, time and place of delivery, interviewer, sex, age (decade born), occupation (original and student/non-student), and environmental group membership (yes/no). The magnitude of the ANOVA statistic was used to interpret the relative differences of ratings within a significant variable. Two simple tests for means, the parametric two-sided t-test and the non-parametric Mann-Whitney test, were also carried out in variables with two possible outcomes to corroborate the differences between means. All tests were done for $95 \%$ confidence. 
The nominal data on value themes were analyzed for proportions based on a $\chi^{2}$ statistic and according to all independent variables, including city, weather (hot/cold), date, time and place of delivery, interviewer, sex, age (decade born), occupation (original and student/non-student), and environmental group membership (yes/no). The $\chi^{2}$ statistics were calculated from contingency tables created to relate the set of responses with the independent variables, which contain the sampling and demographic characteristics. The magnitude of the $\chi^{2}$ statistic was used to interpret the relative distribution of value themes within a significant variable. First and second mentions were analyzed separately. The "no response" code was not included in the $\chi^{2}$ statistical analyses.

\section{RESULTS}

A total of 1077 survey responses were captured, with $38 \%, 37 \%$, and $24 \%$ of those responses recorded in Fredericton, Halifax, and Winnipeg, respectively. There was a strong difference in weather among cities, with Winnipeg having $79 \%$ of responses in hot conditions and Halifax having $62 \%$ of responses in cold conditions.

The demographic characteristics of respondents between cities were similar for sex $(52 \%$ female, $48 \%$ male overall) but differed in decade born and occupation. There was a strong age difference between Halifax, with $64 \%$ of respondents born in the 1980s and 1990s, and Winnipeg and Fredericton, with $77 \%$ and $62 \%$ of respondents born in or before the 1970s, respectively. The two most-frequent occupation codes for all cities were students and retirees, with the latter being more frequent only in Winnipeg (17\%). Recoding the occupation data proved useful to observe the unequal distribution of students and non-students between cities, with nonstudents accounting for $50 \%$ of responses in Halifax but accounting for $77 \%$ and $90 \%$ of responses in Fredericton and Winnipeg, respectively.

Table 2. Ratings of importance for urban forests indicating sampling and demographic characteristic, and relevant statistics, based on the survey results from Fredericton, Halifax, and Winnipeg.

\begin{tabular}{|c|c|c|c|c|c|}
\hline \multirow{2}{*}{$\begin{array}{l}\text { Sampling and } \\
\text { demographic } \\
\text { characteristics }\end{array}$} & \multirow{2}{*}{$\begin{array}{l}\text { Mean of Rating } \\
( \pm \text { margin of } \\
\text { error })^{z}\end{array}$} & \multirow{2}{*}{$\begin{array}{l}\% \text { of total } \\
\text { responses }^{y}\end{array}$} & \multicolumn{3}{|c|}{ Statistics ( $P$-value) } \\
\hline & & & $\begin{array}{l}\text { One-way } \\
\text { ANOVA }^{x}\end{array}$ & $\begin{array}{l}\text { Two-tailed } \\
\text { t-test }{ }^{\mathrm{x}}\end{array}$ & $\begin{array}{l}\text { Mann-Whitney } \\
\text { test }^{x}\end{array}$ \\
\hline \multicolumn{6}{|l|}{ City } \\
\hline Fredericton & $4.6( \pm 0.04)$ & $38 \%$ & 0.018 & $\mathrm{n} / \mathrm{a}$ & $\mathrm{n} / \mathrm{a}$ \\
\hline Halifax & $4.6( \pm 0.03)$ & $37 \%$ & & & \\
\hline Winnipeg & $4.7( \pm 0.03)$ & $24 \%$ & & & \\
\hline \multicolumn{6}{|l|}{ Weather } \\
\hline Cold & $4.3( \pm 0.15)$ & $60 \%$ & $<0.0001$ & $<0.0001$ & $<0.0001$ \\
\hline Hot & $4.8( \pm 0.03)$ & $40 \%$ & & & \\
\hline \multicolumn{6}{|l|}{$\operatorname{Sex}$} \\
\hline Female & $4.7( \pm 0.02)$ & $53 \%$ & 0.001 & 0.006 & $<0.0001$ \\
\hline Male & $4.6( \pm 0.03)$ & $47 \%$ & & & \\
\hline \multicolumn{6}{|c|}{ Age (decade born) } \\
\hline $1920 \mathrm{~s}$ & $5.0( \pm 0.00)$ & $01 \%$ & $<0.0001$ & $\mathrm{n} / \mathrm{a}$ & $\mathrm{n} / \mathrm{a}$ \\
\hline $1930 \mathrm{~s}$ & $4.9( \pm 0.02)$ & $04 \%$ & & & \\
\hline $1940 \mathrm{~s}$ & $4.9( \pm 0.03)$ & $09 \%$ & & & \\
\hline $1950 \mathrm{~s}$ & $4.9( \pm 0.02)$ & $14 \%$ & & & \\
\hline $1960 \mathrm{~s}$ & $4.8( \pm 0.05)$ & $14 \%$ & & & \\
\hline $1970 \mathrm{~s}$ & $4.6( \pm 0.07)$ & $14 \%$ & & & \\
\hline $1980 \mathrm{~s}$ & $4.5( \pm 0.05)$ & $28 \%$ & & & \\
\hline $1990 \mathrm{~s}$ & $4.5( \pm 0.06)$ & $16 \%$ & & & \\
\hline \multicolumn{6}{|l|}{ Occupation } \\
\hline Student & $4.5( \pm 0.04)$ & $30 \%$ & $<0.0001$ & $<0.0001$ & 0.02 \\
\hline Non-student & $4.7( \pm 0.02)$ & $70 \%$ & & & \\
\hline \multicolumn{6}{|c|}{ Environmental group membership } \\
\hline Yes & $4.7( \pm 0.06)$ & $10 \%$ & 0.229 & 0.244 & 0.128 \\
\hline No & $4.6( \pm 0.02)$ & $90 \%$ & & & \\
\hline
\end{tabular}

${ }^{z}$ Margin of error based on a 95\% confidence interval. Means are based on a scale from 1 to 5 , with 5 being highest.

$\mathrm{y}$ Total responses $=1077$. Percentages may not add to $100 \%$ due to rounding.

x Based on a $95 \%$ confidence level (critical $P$-value $=0.05)$. 
The average rating of importance for trees in the city across all cities was high (Mean $=4.64$, Standard Error $=0.04$, at $95 \%$ confidence level) with only small differences in mean ratings across sampling and demographic characteristics (Table 2). The statistical analyses showed a significant difference in ratings among cities, weather conditions, and age (decade born) and occupation (student/non-student) of respondents (Table 2). Rating analyses yielding results thatwerenotstatisticallysignificantwerenotreported.

When asked what they considered important about the trees in the city respondents mostly referred to aesthetics, air quality, shade, naturalness, and environmental quality, among other themes (Table 3$)$. The re-coding of oxygen $(10 \%$ of all responses for all three cities; see DISCUSSION) to air quality did not affect the position of air quality, in terms of its frequency of mention, relative to other themes. The $\chi^{2}$ analyses indicated a significant difference in value theme proportions among cities and weather conditions
(Table 4). $\chi^{2}$ analyses yielding results that were not statistically significant were not reported.

\section{DISCUSSION}

\section{Demographics}

The samples' demographic profile was characterized by young respondents (i.e., born in the 1980s and 1990s), who were mostly students. Considering that no prior experience with this method exists in the urban forest values literature, the authors can only speculate why this is so. It is likely that these two factors are associated. Halifax is the city that best displays this profile and this may because of the presence of five universities in the city and the high presence of young people (20-29 year olds; Statistics Canada 2012). The profile may also be influenced by the time of year and location of survey delivery. First, the researchers speculate that either there are fewer university students or those students do not identify as such during the summer. This seems to explain

Table 3. Value themes derived from what respondents in Fredericton, Halifax, and Winnipeg considered important about the urban forest, indicating percentages of first and second mentions according to city and weather.

\begin{tabular}{|c|c|c|c|c|c|}
\hline \multirow[t]{3}{*}{ Value themes codes ${ }^{z}$} & \multicolumn{3}{|l|}{ Cities } & \multicolumn{2}{|l|}{ Weather } \\
\hline & Fredericton & Halifax & Winnipeg & Hot & Cold \\
\hline & 1st-2nd mention & 1st-2nd mention & 1st-2nd mention & 1st-2nd mention & 1st-2nd mention \\
\hline Aesthetics & $11 \%-6 \%$ & $11 \%-6 \%$ & $6 \%-4 \%$ & $10 \%-6 \%$ & $18 \%-9 \%$ \\
\hline Air & $10 \%-5 \%$ & $10 \%-4 \%$ & $3 \%-5 \%$ & $8 \%-7 \%$ & $16 \%-7 \%$ \\
\hline Shade & $4 \%-3 \%$ & $2 \%-1 \%$ & $6 \%-3 \%$ & $8 \%-4 \%$ & $3 \%-3 \%$ \\
\hline Naturalness & $2 \%-1 \%$ & $3 \%-1 \%$ & $4 \%-2 \%$ & $4 \%-2 \%$ & $5 \%-2 \%$ \\
\hline Environmental quality & $3 \%-2 \%$ & $3 \%-2 \%$ & $2 \%-2 \%$ & $3 \%-3 \%$ & $4 \%-3 \%$ \\
\hline Sense of place & $1 \%-1 \%$ & $3 \%-1 \%$ & $1 \%-1 \%$ & $1 \%-1 \%$ & $3 \%-2 \%$ \\
\hline Personal well-being & $2 \%-1 \%$ & $1 \%-1 \%$ & $0 \%-0 \%$ & $1 \%-1 \%$ & $2 \%-2 \%$ \\
\hline Biodiversity & $2 \%-2 \%$ & $1 \%-1 \%$ & $0 \%-1 \%$ & $1 \%-2 \%$ & $2 \%-2 \%$ \\
\hline Recreation & $0 \%-0 \%$ & $1 \%-0 \%$ & $1 \%-0 \%$ & $0 \%-0 \%$ & $1 \%-1 \%$ \\
\hline Spiritual & $0 \%-0 \%$ & $1 \%-0 \%$ & $0 \%-0 \%$ & $0 \%-0 \%$ & $1 \%-1 \%$ \\
\hline Carbon & $0 \%-0 \%$ & $1 \%-0 \%$ & $0 \%-0 \%$ & $0 \%-0 \%$ & $1 \%-1 \%$ \\
\hline Other $^{\mathrm{y}}$ & $2 \%-1 \%$ & $2 \%-1 \%$ & $1 \%-2 \%$ & $2 \%-2 \%$ & $3 \%-2 \%$ \\
\hline
\end{tabular}

Table 4. $\chi^{2}$ statistics for the proportion of value themes according to city and weather, indicating values for first and second mention, based on the survey results from Fredericton, Halifax, and Winnipeg.

\begin{tabular}{|c|c|c|c|}
\hline Sampling characteristics & $\chi^{2 z}$ & Degrees of freedom & $P$-value ${ }^{y}$ \\
\hline \multicolumn{4}{|l|}{$\overline{\text { Cities }}$} \\
\hline Fredericton & 132.16 (1st mention) & 22 & $<0.0001$ \\
\hline \multicolumn{4}{|l|}{ Halifax } \\
\hline Winnipeg & 58.88 (2nd mention) & 22 & $<0.0001$ \\
\hline \multicolumn{4}{|l|}{ Weather } \\
\hline Cold & 68.25 & 11 & $<0.0001$ \\
\hline Hot & 18.51 & 11 & 0.071 \\
\hline
\end{tabular}

${ }^{z}$ The $\chi^{2}$ statistic was calculated based on contingency tables that do not include the "no responses" code, which accounts for $1.2 \%$ of all first mentions and $40 \%$ of all second mentions of the total responses $(\mathrm{n}=1077)$.

y Based on a $95 \%$ confidence level (critical $P$-value $=0.05)$. 
the case of Winnipeg, which was surveyed mostly during the summer and its respondents were older and usually non-student (77\% born in or before the 1970 s; $17 \%$ retirees). Second, most of the universities in these three cities are close to the city center. Given that all places chosen for survey delivery were around the city center, where researchers expected a high concentration of people, the presence of students is not surprising. These observations suggest that although some of the city demographics may have been captured with this method, time of year, which is related to seasonal demographic movements, may be a big influence in demographic profiles.

\section{Ratings}

Results indicate that although there is a statistical difference in the importance of urban forests among some demographic categories, this difference is not substantive-almost everyone who participated in the surveys thinks urban forests are important. These results echo previous ones based on different methods, mostly phone and postal surveys (e.g., Lohr et al. 2004; Zhang and Zheng 2011). Generally, the average rating of 4.6 in this study is higher than studies with similar 1-5 ratings, such as that one by Schroeder et al. (2006), with an average rating of approximately 3.6. This may suggest a more positive attitude towards urban trees by the Canadian respondents in these three cities. However, these ratings are ultimately incomparable given that some of the ratings in some of these studies are based solely on trees outside of the respondent's home (Schroeder et al. 2006), individual tree species (Sommer et al. 1989), or street trees in different urban landscapes (Getz et al. 1982).

The analysis suggests that respondents who are female, non-students, in Winnipeg, under hotter conditions, and born in or before the 1960s, rate the trees in the city at a slightly higher level of importance (Table 2). The influence of sex, age, and occupation, which in some cases can reflect income (i.e., non-students in this survey are usually professional employees; see Table 1), on a higher appraisal of the urban forest, is corroborated by the observations of Lohr et al. (2004) in the U.S. This is consistent with the general notion that females have been found to be more concerned for the environment than males (see Liere and Dunlap 1980; Jones and
Dunlap 1992; Dietz et al. 1998). The characteristics of the Winnipeg sample, including hotter weather (related to time of year, not overall climate) and a higher proportion of non-students and people born in or before the 1960s, may account for the high ratings in this city. Ultimately, controlling for weather, which in this survey was only captured as a temperature variation and is ultimately related to the time of year of survey delivery, and urban demographic shifts should be considered in further applications of this or other survey methods in other cities, and may help clarify some of these observations.

\section{Value Themes}

A wide variety of reasons, including aesthetics, air quality, shade, environmental quality (i.e., ideas implying improvement or cleaning of the environment), naturalness, well-being, recreation, biodiversity, and sense of place, among others, were mentioned as to why urban forests are important. In terms of frequency of mention, the top themes were aesthetics, air quality, and shade (Table 3). When compared with other studies (e.g., Chiesura 2004; Flannigan 2005; Schroeder et al. 2006), these results reinforce the common notion that aesthetics is the most-easily elicited value associated with the urban forest. Some authors explain how aesthetics are central to an observer's thought and conscious experience of the urban landscape (Ulrich 1986).

Even if aesthetics is the first thing that comes to people's minds when asked why urban trees are important to them, the results of this study also indicate that people associate air quality, shade, and environmental quality ideas with trees. The importance of shade is echoed in other studies (Lohr et al. 2004), although these results suggest a possible influence of weather, here expressed in terms of temperature variation and related to time of year (Table 4). This means that shade may have been more prominent in the data given that some of the responses were captured during summer months, particularly in Winnipeg, when solar radiation is high and people are more aware of the need for shade. It is difficult to say whether the influence of weather, related to time of year, on people's responses is indicative of a general trend given that other survey-based urban-forest values studies have not reported weather conditions or time of year in their results. 
The survey did not elicit themes that are prominent in the urban forest literature. For instance, the economic value of urban forests is not identified by these survey respondents, although a considerable number of studies refer to the economic value of urban forests (McPherson 2003; Donovan and Butry 2010; Roy et al. 2012; among others). This is also the case for urban forest contributions to human health and physical activity, which were not mentioned by respondents although they are widely discussed (e.g., Giles-Corti and Donovan 2002). One interpretation of this evidence is to observe how this elicitation method did not prompt respondents with answers, thereby intimating that what was captured reflects more of an awareness of respondents' psychological state instead of an intellectual response to a predetermined list of items (see Peckham et al. 2013).

In contrast, the survey captured themes related to naturalness, biodiversity, personal well-being, and sense of place, which evoke how being connected to a natural environment, the ecological quality of the natural space, and the stimulation of positive psychological states, are important to people. These three themes were pointed out by other studies that explored what people consider important in urban woodlands, parks, and residential streets (e.g., Chiesura 2004; Tyrväinen et al. 2007; Arnberger and Eder 2012). Again, these themes do not reflect an intellectual response but rather an awareness of respondents' psychological state. The authors of the current study speculate that these states are generated by the direct experience of the respondents with the urban forest, which echoes ideas found in recent qualitative studies (Peckham et al. 2013; Sinclair et al. 2014).

\section{Limitations and Further Research}

An important limitation for this study was that researchers did not capture some socioeconomic variables, such as income and location of residence, which have been proved to influence people's attitudes toward urban vegetation (e.g., Grove et al. 2006). As explained in the METHODS section, the pilot surveys suggested that the current survey was not adequate to capture such personal information. Nevertheless, more research is needed to investigate how different method designs may help capture these types of data.
It was mentioned that at least some of the difference in ratings of importance among cities could be explained by weather and time of year. Specifically, trees seem to be more important to respondents in Winnipeg, which was surveyed mostly during the summer (Table 2). The authors acknowledge that the difference in ratings may be related to other issues, such as public awareness or concern with urban forest loss. The limited length of the paper does not allow the authors to ponder at length on this matter, and so prefer to focus on what the data imply. Nevertheless, it is important to note that the difference in ratings is minimal (Table2). Ultimately, more research is needed to understand how demographic profiles are affected by time of implementation of a sidewalkinterception survey in different cities in Canada.

The interpretative analysis helped in condensing the ideas related to what respondents considered important about the urban forest. In this process, an informed judgment was made and oxygen was re-coded to air quality. The authors took into consideration that, although trees do produce oxygen, they contribute little to the maintenance of its atmospheric levels at a geological and planetary scale, given the time-frame for oxygen formation, its atmospheric residence, and the significant ocean contributions in oxygen production (Junge 1974). Urban forests in general may contribute little to global oxygen atmospheric levels (Nowak et al. 2007). The authors speculate that respondents deem oxygen production as an important aspect of urban forests based on their early schooling, which tends to create an awareness, instead of providing critical scientific knowledge, of oxygen's atmospheric cycling. Thus, reclassifying oxygen was preferred, and as previously explained, this action did not impact the relative importance of air quality in terms of its frequency of mention. Broadly speaking, the general, public notion that urban trees are mostly important for oxygen production needs to be explored further.

Finally, the authors believe more research is needed to elicit urban forest public values in different geographic locations and to generate ratings about the importance of trees in the city, based on comparable methods. Differences in the themes elicited through different methods suggest that unprompted and experiential methods 
are a better means of capturing at least some of the psychosocial and ecological themes urban residents consider important in urban forests. More research may also be needed to understand why people seem to have a lack of understanding of the economic and health value of urban trees.

\section{CONCLUSION}

While some environmental and aesthetic value themes can be readily elicited from the public, the results here indicate that Canadian urban inhabitants in Fredericton, Halifax, and Winnipeg also associate psychological, social, and ecological values with urban trees when their answers are unprompted. This study also suggests-based on what people say they value about urban forestsurban forest managers could strive for an enhancement of sensory experiences by increasing the naturalness and ecological quality of urban forest spaces and increasing their environmental benefits, such as adding more shade. Ultimately, only a combination of methods can help researchers come closer to a deep understanding of what the general public values about the trees in their cities. The method used here has certainly proved useful in eliciting some value themes that are not usually found in the literature. The study authors deduce that methods intent on capturing the values people assign to the urban forests will be strengthened by enhancing the direct experience between them, since many value themes are not just associated with respondents' intellectual awareness of their environmental and economic importance but also with their psychological states.

Acknowledgments. We wish to thank the following people for their help in the collection and preliminary analysis of the data of this study: in Fredericton, Tom Beckley's students; in Halifax, James Bar, Erin McWilliam, and Alexandra van der Pol; and in Winnipeg, Natasha Szach.

\section{LITERATURE CITED}

Arnberger, A., and R. Eder. 2012. Exploring coping behaviours of Sunday and workday visitors due to dense use conditions in an urban forest. Urban Forestry \& Urban Greening 11(4):439-449.

Balram, S., and S. Dragievi. 2005. Attitudes toward urban green spaces: Integrating questionnaire survey and collaborative GIS techniques to improve attitude measurements. Landscape and Urban Planning.71(2-4):147-162.

Bengston, D.N. 1994. Changing forest values and ecosystem management. Society \& Natural Resources 7:515-533.
Budruk, M., H. Thomas and T. Tyrrell. 2009. Urban green spaces: A study of place attachment and environmental attitudes in India. Society \& Natural Resources 22(9):824-839.

Chiesura, A. 2004. The role of urban parks for the sustainable city. Landscape and Urban Planning 68(1):129-138.

Clark, J.R., N.P. Matheny, G. Cross, and V. Wake. 1997. A model of urban forest sustainability. Journal of Arboriculture 23(1):17-30.

Conway, T., and J. Hackworth. 2007. Urban pattern and land cover variation in the greater Toronto area. The Canadian Geographer/ Le Géographe Canadien 51(1):43-57.

Dietz, T., A. Fitzgerald, and R. Shwom. 2005. Environmental values. Annual Review of Environment and Resources 30:335-372.

Dietz, T., P.C. Stern, and G.A. Guagnano. 1998. Social structural and social psychological bases of environmental concern. Environment and Behavior 30(4):450-471.

Donovan, G.H., and D.T. Butry. 2010. Trees in the city: Valuing street trees in Portland, Oregon. Landscape and Urban Planning 94(2):77-83.

Dutcher, D.D., J.C. Finley, A.E. Luloff, and J.B. Johnson. 2007. Connectivity with nature as a measure of environmental values. Environment and Behavior 39(4):474.

Dwyer, J.F., E.G. McPherson, H.W. Schroeder, and R.A. Rowntree. 1992. Assessing the benefits and costs of the urban forest. Journal of Arboriculture 18(5):227-227.

Dwyer, J.F., H.W. Schroeder, and P.H. Gobster. 1991. The significance of urban trees and forests: Toward a deeper understanding of values. Journal of Arboriculture 17(10):276-284.

Fisher, R.K., R.K. Turner, and P. Morling. 2009. Defining and classifying ecosystem services for decision making. Ecological Economics 68(3):643-653.

Flannigan, J. 2005. An evaluation of residents' attitudes to street trees in southwest England. Arboricultural Journal 28(4):219-241.

Fraser, E.D.G., and W.A. Kenney. 2000. Cultural background and landscape history as factors affecting perceptions of the urban forest. Journal of Arboriculture 26(2):106-113.

Getz, D.A., A. Karow, and J.J. Kielbaso. 1982. Inner city preferences for trees and urban forestry programs. Journal of Arboriculture $8(10): 258-263$.

Giles-Corti, B., and R.J. Donovan. 2002. The relative influence of individual, social, and physical environment determinants of physical activity. Social Science \& Medicine 54(12):1793-1812.

Gobster, P.H., and L.M. Westphal. 2004. The human dimensions of urban greenways: Planning for recreation and related experiences. Landscape and Urban Planning 68(2-3):147-165.

Gorman, J. 2004. Residents' opinions on the value of street trees depending on tree location. Journal of Arboriculture 30(1):36-44.

Grove, M., A.R. Troy, J.P. O’Neil-Dunne, W.R.J. Burch, M.L. Cadenasso, and S.T.A. Pickett. 2006. Characterization of households and its implications for the vegetation of urban ecosystems. Ecosystems 9(4):578-597.

Heberlein, T.A. 2012. Navigating environmental attitudes. Oxford University Press, New York, New York, U.S. 240 pp.

Hull, R.B. 1992. How the public values urban forests. Journal of Arboriculture 18(2):98-101.

Hunter, I.R. 2001. What do people want from urban forestry?The European experience. Urban Ecosystems 5(4):277-284. 
Jay, M., and U. Schraml. 2009. Understanding the role of urban forests for migrants-Uses, perception, and integrative potential. Urban Forestry \& Urban Greening 8(4):283-294.

Johnston, M., and L.D. Shimada. 2004. Urban forestry in a multicultural society. Journal of Arboriculture 30(3):185-192.

Jones, R.E., and R.E. Dunlap. 1992. The social bases of environmental concern: Have they changed over time? Rural Sociology $57: 28-47$.

Jones, R.E., K.L. Davis, and J. Bradford. 2013. The value of trees: Factors influencing homeowner support for protecting local urban trees. Environment and Behavior 45(5):650-676.

Junge, C.E. 1974. Residence time and variability of tropospheric trace gases. Tellus 26(4):477-488.

Kalmbach, K.L., and J.J. Kielbaso. 1979. Resident attitudes toward selected characteristics of street tree planting. Journal of Arboriculture 5(6):124-129.

Lewis-Beck, M.S., A.E. Bryman, and T. Futing Liao. 2003. The SAGE Encyclopedia of Social Science Research Methods. SAGE Publications, Inc., Thousand Oaks, California, U.S. 1528 pp.

Liere, K.D., and R.E. Dunlap. 1980. The social bases of environmental concern: A review of hypotheses, explanations, and empirical evidence. Public Opinion Quarterly 44(2):181-199.

Lockwood, M. 1999. Humans valuing nature: Synthesizing insights from philosophy, psychology, and economics. Environmental Values 8(3):381-401.

Lohr, V., C. Pearson-Mims, J. Tarnai, and D. Dillman. 2004. How urban residents rate and rank the benefits and problems associated with trees in cities. Journal of Arboriculture 30(1):28-35.

McPherson, E.G. 2003. A benefit-cost analysis of ten street tree species in Modesto, California, U.S. Journal of Arboriculture 29(1):1-8.

McPherson, E.G., and J.R. Simpson. 2002. A comparison of municipal forest benefits and costs in Modesto and Santa Monica, California, USA. Urban Forestry \& Urban Greening 1(2):61-74.

Mulhall, J., R. King, S. Glina, and K. Hvidsten. 2008. Importance of and satisfaction with sex among men and women worldwide: Results of the global better sex survey. The Journal of Sexual Medicine 5(4):788-795.

Nowak, D.J., M.H. Noble, S.M. Sisinni, and J.F. Dwyer. 2001. People and trees: Assessing the U.S. urban forest resource. Journal of Forestry 99(3):37-42.

Nowak, D.J., R. Hoehn, and D.E. Crane. 2007. Oxygen production by urban trees in the United States. Arboriculture \& Urban Forestry 33(3):220-226.

Owen, R.J., P.N. Duinker, and T.M. Beckley. 2009. Capturing oldgrowth values for use in forest decision-making. Environmental Management 43(2):237-248.

Payton, S., G. Lindsey, J. Wilson, J. Ottensmann, and J. Man. 2008. Valuing the benefits of the urban forest: A spatial hedonic approach. Journal of Environmental Planning and Management 51(6):717.

Peckham, S., P.N. Duinker, and C. Ordonez. 2013. Urban forest values in Canada: Views of citizens in Calgary and Halifax. Urban Forestry \& Urban Greening 12(2):154-162.

Reser, J.P., and J.M. Bentrupperbäumer. 2005. What and where are environmental values? Assessing the impacts of current diversity of use of 'environmental' and 'World Heritage' values. Journal of Environmental Psychology 25(2):125-146.
Rohan, M.J. 2000. A rose by any name? The values construct. Personality and Social Psychology Review 4(3):255-277.

Rokeach, M. 1973. The Nature of Human Values. John Wiley \& Sons, New York, New York, U.S. 438 pp.

Roy, S., J. Byrne, and C. Pickering. 2012. A systematic quantitative review of urban tree benefits, costs, and assessment methods across cities in different climatic zones. Urban Forestry \& Urban Greening 11(4):351-363.

Ruckelshaus, M., E. McKenzie, H. Tallis, A. Guerry, G. Daily, P. Kareiva, S. Polasky, T. Ricketts, N. Bhagabati, S.A. Wood, and J. Bernhardt. 2013. Notes from the field: Lessons learned from using ecosystem service approaches to inform real-world decisions. Ecological Economics (in press).

Satterfield, T. 2001. In search of value literacy: Suggestions for the elicitation of environmental values. Environmental Values 10(3):331-359.

Schroeder, H., J. Flannigan, and R. Coles. 2006. Residents' attitudes toward street trees in the UK and U.S. communities. Journal of Arboriculture \& Urban Forestry 32(5):236-246.

Schroeder, H.W. 1984. Environmental perception rating scales a case for simple methods of analysis. Environment and Behavior 16(5):573-598.

Schroeder, H.W., and S.R. Ruffolo. 1996. Householder evaluations of street trees in a Chicago suburb. Journal of Arboriculture 22(1):35-43.

Schultz, P.W. 2002. Inclusion with nature: The psychology of humannature relations. pp. 61-78. In: P. Schmuck and P.W. Schultz (Eds.). The psychology of sustainable development. Kluwer, New York, New York, U.S. 327 pp.

Schwartz, S.H. 1992. Universals in the content and structure of values: Theoretical advances and empirical tests in 20 countries. Advances in Experimental Social Psychology 25(1):1-65.

Schwartz, S.H., and W. Bilsky. 1990. Toward a theory of the universal content and structure of values: Extensions and cross-cultural replications. Journal of Personality and Social Psychology 58(5):878-891.

Sinclair, J.A., J. Diduck, and P.N. Duinker. 2014. Elicitation of urban forest values from residents of Winnipeg, Canada. Canadian Journal of Forest Research 44(8):922-930.

Sommer, R., H. Guenther, and P.A. Barker. 1990. Surveying householder response to street trees. Landscape Journal 9(2):79-85.

Sommer, R.O., P.A. Barker, H. Guenther, and K. Kurani. 1989. Householder evaluation of two street tree species. Journal of Arboriculture 15(4):99-102.

Statistics Canada. 2006. Population and dwelling counts for Canada and census subdivisions (municipalities), 2006 and 2001 censuses-100\% data. Statistics Canada. Accessed 30 December 2013. <www12.statcan.ca/english/census06/data/popdwell/ Table.cfm? $=301 \& S=3 \& \mathrm{O}=\mathrm{D}$ 2010>

Statistics Canada. 2012. Focus on Geography Series, 2011 CensusCensus subdivision of Halifax, RGM, Nova Scotia. Statistics Canada. Accessed 30 December 2013. <www12.statcan. gc.ca/census-recensement/2011/as-sa/fogs-spg/Facts-csd-eng. cfm?LANG=Eng\&GK=CSD\&GC $=1209034>$

Strauss, A.L., and J. Corbin. 2008. Basics of qualitative research, third edition. SAGE Publications, Inc., Thousand Oaks, California, U.S. 312 pp.

Treiman, T., and J. Gartner. 2005. What do people want from their community forests? Results of a public attitude survey in Missouri, U.S. Journal of Arboriculture 31(5):243-250. 
Tyrväinen, L., K. Mäkinen, and J. Schipperijn. 2007. Tools for mapping social values of urban woodlands and other green areas. Landscape and Urban Planning 79(1):5-19.

Ulrich, R.S. 1986. Human responses to vegetation and landscapes. Landscape and Urban Planning 13:29-44.

van Wassenaer, P.J.E., L. Schaeffer, and W.A. Kenney. 2000. Strategic planning in urban forestry: A 21st century paradigm shift for small town Canada. Forestry Chronicle 76(2):241-246.

Zhang, Y., and B. Zheng. 2011. Assessments of citizen willingness to support urban forestry: An empirical study in Alabama. Arboriculture \& Urban Forestry 37(3):118-125.

Camilo Ordóñez

Dalhousie University

School for Resource and Environmental Studies

6100 University Avenue Suite 5010

Halifax, Nova Scotia B3H3J5

Canada

Peter N. Duinker (corresponding author)

Professor

Dalhousie University

School for Resource and Environmental Studies

6100 University Avenue, Suite 5010

Halifax NS B3J $3 \mathrm{H} 5$

Canada

Phone: 1-902-494-7100

Fax: 1-902-494-3728

Email:peter.duinker@dal.ca

A. John Sinclair

University of Manitoba

Natural Resources Institute

Winnipeg, Manitoba

Canada

Tom Beckley

University of New Brunswick

Forestry \& Environmental Management

Fredericton, New Brunswick

Canada

Jaclyn Diduck

University of Manitoba

Natural Resources Institute

Winnipeg, Manitoba

Canada 
Résumé. Considérant que la majorité de la population du Canada est concentrée dans les villes, il est important de déterminer ce que les gens considèrent comme important dans la nature en milieu urbain. Le concept de valeurs peut aider à illustrer ce que les gens considèrent comme important dans la nature urbaine au-delà des considérations purement fonctionnelles. Ce qui est le cas des forêts urbaines. Cependant, de nombreuses études sur l'opinion du public à l'endroit des forêts urbaines ne tiennent pas compte des perceptions sur leur importance, ne mettent pas l'accent sur l'ensemble des arbres de la ville ou n'offrent pas aux répondants des opportunités de vécu en lien avec les forêts urbaines. Au Canada, la plupart des hypothèses sur les valeurs des forêts urbaines canadiennes sont basées sur des études provenant des États-Unis.

Dans cette étude, les chercheurs présentent et analysent les données sur les valeurs des forêts urbaines recueillies à la suite d’enquêtes sur le terrain réalisées dans les villes de Frédéricton, au NouveauBrunswick, de Halifax en Nouvelle-Écosse et de Winnipeg au Manitoba au Canada, pour résoudre certaines des limitations mentionnées ci-haut. On a demandé aux répondants d'évaluer le niveau d'importance des forêts urbaines et d'en identifier les raisons. Les résultats montrent que les répondants accordent à la forêt urbaine une importance élevée en raison de l'aspect esthétique, de la qualité de l'air, de l'ombre qu'elle génère et du caractère naturel qu'elle procure, entre autres justifications. Il a été constaté une tendance à évaluer les forêts urbaines à un niveau d'importance plus élevé particulièrement chez les personnes âgées, les femmes et ceux qui n'étaient pas des étudiants. Le climat, en lien avec la période de l'année où étaient réalisées les enquêtes, exerçait une influence sensible sur la prépondérance des diverses thématiques lors de la collecte des données. Les auteurs de l'étude concluent que cette méthode permet de saisir des données sur létat psychologique des répondants plutôt que leur prise de conscience intellectuelle selon ce qu'ils considèrent comme important concernant les forêts urbaines.

Zusammenfassung. Weil die Mehrheit der kanadischen Bevölkerung in Städten konzentriert ist, ist es wichtig zu bestimmen, was die Menschen an der Urbanen Natur für wichtig erachten. Das Konzept von Werten kann dabei helfen zu illustrieren, was die Menschen über die Frage der Nützlichkeit hinaus an der Urbanen Natur für wichtig erachten. Das ist der Fall bei Urbanen Wäldern. Dennoch erzielen viele der Studien über die öffentliche Meinung zu Urbanen Wäldern keine Aussagen zur Bedeutung, fokussieren auf allen Bäumen der Stadt oder liefern Antworten von Menschen mit direkter Erfahrung urbaner Wälder. In Kanada basieren die meisten Annahmen über kanadische Stadtwälder auf Ergebnissen aus den USA.

In dieser Studie präsentieren und analysieren Forscher den Wert urbaner Wälder anhand von Daten aus einer Umfrage auf dem Gehweg in den Städten Fredericton, New Brunswick; Halifax, Nova Scotia; und Winnipeg, Manitoba, Canada, um einigen dieser Begrenzungen entgegenzutreten. Die Antwortenden wurden gefragt, den Level von Bedeutung urbaner Wälder zu bewerten und die Gründe dafür zu nennen. Die Ergebnisse zeigen, dass die Antwortenden die urbanen Wälder für wichtig erachten und die Gründe dafür sind unter anderem: Ästhetik, Luftqualität, Schatten und Natürlichkeit. Es gab eine Tendenz bei alten Menschen, Frauen und Nichtstudenten, die urbanen Wälder höher zu bewerten. Wetter in Verbindung mit der Jahreszeit, wann die Umfrage durchgeführt wurde, hatte einen wahrnehmbaren Einfluss auf die Art und Weise, wie Wertethemen in den Daten verteilt sind. Die Autoren dieser Studie leiten davon ab, diese Methode hilft, Daten eher von dem psychologischen Standpunkt der Befragten als von ihrem intellektuellen Bewusstsein, was sie für wichtig erachten, zu gewinnen.

Resumen. Con la mayoría de la población de Canadá concentrada en las ciudades, es importante determinar lo que la gente considera importante en la naturaleza urbana. Más allá de consideraciones utilitarias, el concepto de los valores puede ayudar a ilustrar lo que la gente considera importante en la naturaleza urbana. Este es el caso de los bosques urbanos. Sin embargo, muchos estudios acerca de la opinión pública sobre los bosques urbanos no capturan expresiones de importancia, se centran en todos los árboles de la ciudad, o proporcionan los encuestados con una experiencia directa de los bosques urbanos. En Canadá, la mayoría de los supuestos sobre los valores forestales urbanos canadienses se basan en los resultados de los Estados Unidos.

En este estudio los investigadores presentan y analizan los datos forestales urbanos recogidos con una encuesta en la intercepción de una acera en las ciudades de Fredericton, New Brunswick; Halifax, Nueva Escocia; y Winnipeg, Manitoba, Canadá, para abordar algunas de estas limitaciones. Se pidió a los encuestados con el fin de medir el nivel de importancia de los bosques urbanos y hablar de las razones. Los resultados muestran que los encuestados valoran el bosque urbano en un alto nivel de importancia y las razones para ello son la estética, la calidad del aire, la sombra y la naturalidad, entre otros temas. Hubo una tendencia a que las personas mayores, las mujeres, y no estudiantes evalúen los bosques urbanos en un mayor nivel de importancia. El clima, relacionado con la época del año de la entrega encuesta, tiene una influencia perceptible en la forma en que los temas se distribuyen en los datos. Los autores del estudio infieren que este método ayuda a capturar datos sobre los estados psicológicos de los encuestados, en lugar de su conciencia intelectual, en cuanto a lo que ellos consideran importante acerca de los bosques urbanos. 